\title{
Identification Cold Tolerance of Pineapple Germplasms at Seedling Stage
}

\author{
Haiyan Shu, Keming Li, Yanfei Ou, Rulin Zhan, Shenghe Chang* \\ Haikou Experimental Station, Chinese Academy of Tropical Agricultural Sciences, Haikou, China \\ Email: *plantfood772@catas.cn
}

How to cite this paper: Shu, H.Y., Li, K.M., Ou, Y.F., Zhan, R.L. and Chang, S.H. (2021) Identification Cold Tolerance of Pineapple Germplasms at Seedling Stage. American Journal of Plant Sciences, 12, 1768-1779. https://doi.org/10.4236/ajps.2021.1212123

Received: October 29, 2021

Accepted: December 5, 2021

Published: December 8, 2021

Copyright $\odot 2021$ by author(s) and Scientific Research Publishing Inc. This work is licensed under the Creative Commons Attribution International License (CC BY 4.0).

http://creativecommons.org/licenses/by/4.0/ (c) (i) Open Access

\begin{abstract}
Pineapple plant was always injured due to low temperature. Breeding varieties with high cold tolerance was the supreme way to resolve this problem and identifying cold tolerance of germplasms collected was necessary. In this study, SSR locus around homologous sequences of cold-tolerant genes was searched and screened using MD-2 (cold-tolerant variety) and Tainong 17 (cold-sensitive variety). Seventy three pairs of primers of which PCR results were different between these two varieties were gotten. PCRs were performed using these as primers and genomic DNA of germplasms collected as templates. Six pairs of primers were found that their PCR results were in good consistent with cold tolerance. Using GLM (General linear model) association mapping analysis, two SSR markers linked to cold tolerance were found. Their efficiency was verified further using pineapple germplasms with high cold tolerance which had been validated in field by cold wave. They will be used in cold-tolerant breeding of pineapple in the future.
\end{abstract}

\section{Keywords}

Pineapple, Cold Tolerance, Seedling Stage, Simple Sequence Repeat (SSR), Breeding

\section{Introduction}

Pineapple plants were sensitive to low temperature. Only when temperature was higher than $14^{\circ} \mathrm{C}$, pineapple plants begin to grow [1]. Most cultivars are injured during winter periods, especially in sub-tropical regions [2]. Almost all pineapple varieties are injured after exposure to $4^{\circ} \mathrm{C}$ for 24 hours [2]. In 2021, the lowest temperature in Fujian province, China was only $2^{\circ} \mathrm{C}$. Many pineapple plants died because of low temperature. Although suspending sheets or plastic over pineapple plants can provide protection in a certain extent, they increase cost, re- 
duce profit and are not sufficiently effective [2]. Cultivating new varieties with high tolerance to cold was the supreme way for resolving this problem.

Collecting germ plasm resource and identifying their characteristics was the first step for pineapple breeding [3]. The direct way for identifying cold tolerance was planting the materials in field and observing their cold tolerance in winter. However, this method needs much labor and time. Furthermore, people cannot be sure whether cold wave passes experimental field or not at a certain stage. If molecular markers related with cold tolerance can be developed, cold tolerance of many germ plasm resources can be identified in short time.

Using two rice genes analog (RGA) primers, the genetic variability and relationships among 265 rice germplasm accessions with different resistance to rice Tungro virus were analyzed, and 48 polymorphic bands in the germplasm samples with an average of 28.6 bands per accessions were gotten [4]. Using similar method, 14 pairs of primers related with glucosinolates (GS) biosynthesis in Chinese cabbage were amplified in 75 accessions and produced 26 SSR alleles [5]. Using GLM (General linear model) association mapping analysis, four SSR markers linked with GS were gotten [5]. These demonstrated that molecular markers always located near to the genes with similar functions. Molecular markers can be found around these genes. Developing molecular markers related with certain genes was feasible.

There were many cold-tolerant genes in plant. In this study, homologous sequences of these cold tolerant genes were found. Simple sequence repeat (SSR) locus was screened in 5-kb upstream and downstream around these sequences. Certain cold-tolerant variety and cold-sensitive variety were used to screen these SSR primers. PCRs were performed using those primers of which the PCR results were different between cold-tolerant variety and cold-sensitive variety and genomic DNA of pineapple germplasms collected as template. Comparing with the cold tolerance of these pineapple germplasms, two SSR primers and two markers linked to cold tolerance were gotten. Their efficiency was verified further using pineapple germplasms with high cold tolerance which had been validated in field by cold wave. They will be used in cold-tolerant breeding of pineapple in the future.

\section{Materials and Methods}

\section{Plant materials}

MD-2 was the most tolerant variety to cold [6]. Tainong 17 was the most sensitive variety to cold [6]. Pineapple varieties Tainong 17, Tainong 16, Tainong 21, Tanong 4, Xigua, MD-2, Dongmi, Niunai, Bali, Giant Kew, Kallara Local, Moris, New Phuket, Tradsrithong, Pattavia, Perola, Peral, Smooth cayenne, Ripley, Phetchaburi\#2, Vietnam queen were also used in this study. They were gotten from Southern-asian tropical crop institute, Chinese Academy of tropical agricultural sciences. Cold-resistant germplasms (3 - 9, 3 - 11, 3 - 16, 3 - 19, 3 26,3 - 31, 3 - 33, 3 - 34, 3 - 37, 4 - 12, 4 - 13, 4 - 25, 4 - 36, 4 - 50, 4 - 52, 4 - 54) were donated from Professor Liu Chuanhe, who worked in the Institute of Fruit 
Trees, Guangdong Academy of Agricultural Sciences. All of the plant materials were grown in experimental field of Haikou Experimental Station, Chinese Academy of Tropical Agricultural Sciences, in Danzhou, Hainan Province.

Cold tolerance determination for pineapple varieties

Plants growth were determined according the paper published [7]. Tissue-culture seedlings were grown in pot in which gardening soil was put. When the fifth leaf appeared, the seedlings were put in $7^{\circ} \mathrm{C}$ chamber for 5 days. And then, the seedings were returned to $26^{\circ} \mathrm{C}$ for 15 days. On the $16^{\text {th }}$ day, area of the second leaf of the plant was measured. After seedlings were cultured on MSO medium for two months, they were transferred into $4^{\circ} \mathrm{C}$ chamber for 7 days. And then, they were returned to $26^{\circ} \mathrm{C}$ for 15 days. On the $16^{\text {th }}$ day, scorched area of the fourth leaf versus the area of the whole leaf (SCFA) was measured.

Determination of the target genes and searching SSR locus

According to the papers published, plant cold-resistant genes were determined (Table 1). Their homologous sequences were blasted using "Search annotation" and in pineapple genome

(http://pineapple.angiosperms.org/pineapple/html/annotation.php). According to the sequence $5-\mathrm{kb}$-upstream, the gene itself and 5-kb-downstream, using the software FASTPCR 6.0, gene-specific SSR were found. The shortest length of the sequence searched was $12 \mathrm{bp}$. Single nucleotide and double nucleotides were repeated 6 times at least. Trinucleotides, tetrnucleotides, and pentnucleotides were repeated 5 times at least.

\section{Designation of SSR primers}

According to the sequence of SSR locus, 500-bp-upstream sequence and 500-bp-downstream sequence were selected. Primers were designed using the software Primer 3.0

(http://Frodo.wi.mit.edu/cgibin/primer3/primer3-WWW.cgi). Two hundreds and seventy six pairs of primers were designed and synthesized by Sangon Biotech (Shanghai, China).

\section{PCR amplification and product measurement}

$1 \mu \mathrm{l} \mathrm{P} 1,1 \mu \mathrm{l} \mathrm{P} 2,10 \mu \mathrm{l} 2 \times$ PCR buffer, $4 \mu \mathrm{ldNTPs}(2.5 \mathrm{mmol} / \mathrm{L}), 1 \mu \mathrm{l}$ KODFX Taq, $1 \mu \mathrm{l} \mathrm{DNA}, 2 \mu \mathrm{l}$ water were mixed. $94^{\circ} \mathrm{C}$ predenaturation for 4 minutes. $94^{\circ} \mathrm{C}$ denaturation for 30 seconds. $55^{\circ} \mathrm{C}-58^{\circ} \mathrm{C}$ annealing for 30 seconds. $68^{\circ} \mathrm{C}$ extention foe 1 minute. 40 cycles. $68^{\circ} \mathrm{C}$ extention 10 minutes. The products were stored in negative $20^{\circ} \mathrm{C}$ freezer. PCR products were measured using agarose gel or SDS-PAGE gel. Agarose gel was dyed using goldview. SDS-PAGE gel was dyed using silver nitrate.

\section{Analysis for marker polymorphism}

Electrophoresis data was counted using digital matrix. The result without band was recorded as 0 . The result with band was recorded as 1 . Bands amplified by each SSR primer were counted. Total bands corresponding to each pair of primers were counted. The average bands for each pair of primers were calculated. The varieties without band, with 1 band or more than 1 band were counted. 
Table 1. Plant cold-resistant genes used in this study.

\begin{tabular}{|c|c|c|c|}
\hline Gene family & Gene & Origin & Reference \\
\hline $\begin{array}{l}\text { Stearoyl-acyl carrier protein } \\
\text { desaturase gene SAD }\end{array}$ & SsSAD & Sapiums ebiferum & {$[8]$} \\
\hline C-repeat binding factor $\mathrm{CBF}$ & PeCBF4a & Populus euphratica & [9] \\
\hline $\begin{array}{l}\text { Basic helix-loop-helix bHLH } \\
\text { DNA-binding superfamily } \\
\text { protein gene bHLH }\end{array}$ & VabHLH1 & Vitis vinifera & {$[10]$} \\
\hline Inducer of CBF expression gene ICE & PmICE1 & Prunus mume & {$[11]$} \\
\hline $\begin{array}{l}\text { Dehydration responsive element } \\
\text { binding factor gene DREB1 }\end{array}$ & DmDREBa & $\begin{array}{l}\text { Dendranthema } \\
\text { morifolium }\end{array}$ & {$[12]$} \\
\hline Cold regulated gene COR & Cor $15 a$ & Arabidopsis thaliana & {$[13]$} \\
\hline $\begin{array}{c}\text { S-adenosylmethionine } \\
\text { decarboxylase gene SAMDC }\end{array}$ & HbSAMDC1 & Hevea brasiliensis & {$[14]$} \\
\hline $\begin{array}{c}\text { Bidirectional sugar transporter } \\
\text { gene SWEET }\end{array}$ & CsSWEET16 & Camellia sinensis & {$[15]$} \\
\hline antifreeze protein gene AFP & LpAFP & Lolium perenne & {$[16]$} \\
\hline $\begin{array}{c}\text { Late embryogenesis abundant } \\
\text { protein gene LEA }\end{array}$ & CpLEA5 & $\begin{array}{l}\text { Chimonanthus } \\
\text { praecox }\end{array}$ & {$[17]$} \\
\hline Ethylene response factor gene ERF & MfERF1 & Medicago falcata & {$[18]$} \\
\hline $\begin{array}{l}\text { Alkaline/neutral invertase } \\
\text { gene A/NINV }\end{array}$ & PtrA/NINV & Poncirus trifoliata & [19] \\
\hline Fatty acid desaturase gene FAD & AtFAD7 & Arabidopsis thaliana & [7] \\
\hline $\begin{array}{c}\text { Glycerol-3-phosphate } \\
\text { acyltransferase gene GPAT }\end{array}$ & AtGPAT1 & $\begin{array}{c}\text { Arabidopsis } \\
\text { thaliana }\end{array}$ & {$[20]$} \\
\hline $\begin{array}{c}\mathrm{Cu} / \mathrm{Zn} \text { Superoxide } \\
\text { Dismutase Gene SiCSD }\end{array}$ & SiCSD & $\begin{array}{l}\text { Saussurea } \\
\text { involucrata }\end{array}$ & {$[21]$} \\
\hline bZIP transcription factor HY5 & MdHY5 & Malus domestica & {$[22]$} \\
\hline Ascorbate peroxidase gene APX & CaAPX & Camellia azalea & {$[15]$} \\
\hline Small heat shock protein genes HSP & CsHSP17.7 & Camellia sinensis & {$[23]$} \\
\hline Dehydrin-like gene SiDhn2 & SiDhn2 & Saussurea involucrata & {$[24]$} \\
\hline $\begin{array}{l}\text { C-repeat/dehydration responsive } \\
\text { element binding factor gene }\end{array}$ & GhCBF I & Gossypium hirsutum & {$[25]$} \\
\hline
\end{tabular}

\section{Dendrogram construction using NTSYS software}

All of the electrophoresis data were counted as digital matrix. These data were imported into EXCEL file and saved as A.xls. Excel files were saved as the mode that the software can distinguish. $\mathrm{Al}=1$ represented having markers. $\mathrm{B} 1=223$ showed the total markers. $\mathrm{Cl}=43$ showed the genotypes. $\mathrm{D} 1=2$ showed without marker. Since A3, all of the SSR primers were tagged. Since B2, all of the genotypes were tagged in the second line. And then, a digital matrix was gotten. The 
software NTSYS was run and computed. The dendrogram can be gotten.

\section{Association analysis}

General linear model (GLM) in software TASSEL3.0 was used for association analysis. Q data of each variety was used as covariant. Regression analysis was performed between SSR markers and data about cold tolerance identification. The equation of regression analysis was trait $=$ population structure + marker effect + residual.

\section{Results}

1) Cold tolerance of pineapple varieties

Tissue-culture seedlings of pineapple varieties were grown in soil. When the fifth leaf appeared, the seedlings were transferred into $4^{\circ} \mathrm{C}$ chamber. After 7 days, the seedlings were returned to $26^{\circ} \mathrm{C}$ for 15 days. Results showed that after pineapple seedlings were treated with low temperature, MD-2 grew the most fast among the varieties. Tainong 17 and Peral grew the slowest. When scorched area of the fourth leaf from the apex (SCFA) was measured, it was found that SCFA value of MD-2 was the least, while that values of Tainong17 was the most (Figure 1 and Figure 2). These demonstrated that MD-2 was the most cold-tolerant variety among the materials. Tainong 17 was the most cold-sensitive variety.

2) Cold-tolerant genes in pineapple genome and SSR locus

The homologous sequences of Bhlh, COR, SAMDC, SWEET, LEA, HSP, GPAT, FAD were found in pineapple genome. The homologous sequences of other cold-tolerant genes, such as SAD, CBF, CRT/DRE, AFP, A/NINV, SiCSD, HY5, SiDhn2 had not been found in pineapple genome. One hundred and sixty nine cold-tolerant genes were found in pineapple genome, including 4 FAD genes, 20 GPAT genes, 112 bHLH genes, 5 COR genes, 3 SAMDC genes, 1 SWEET gene,
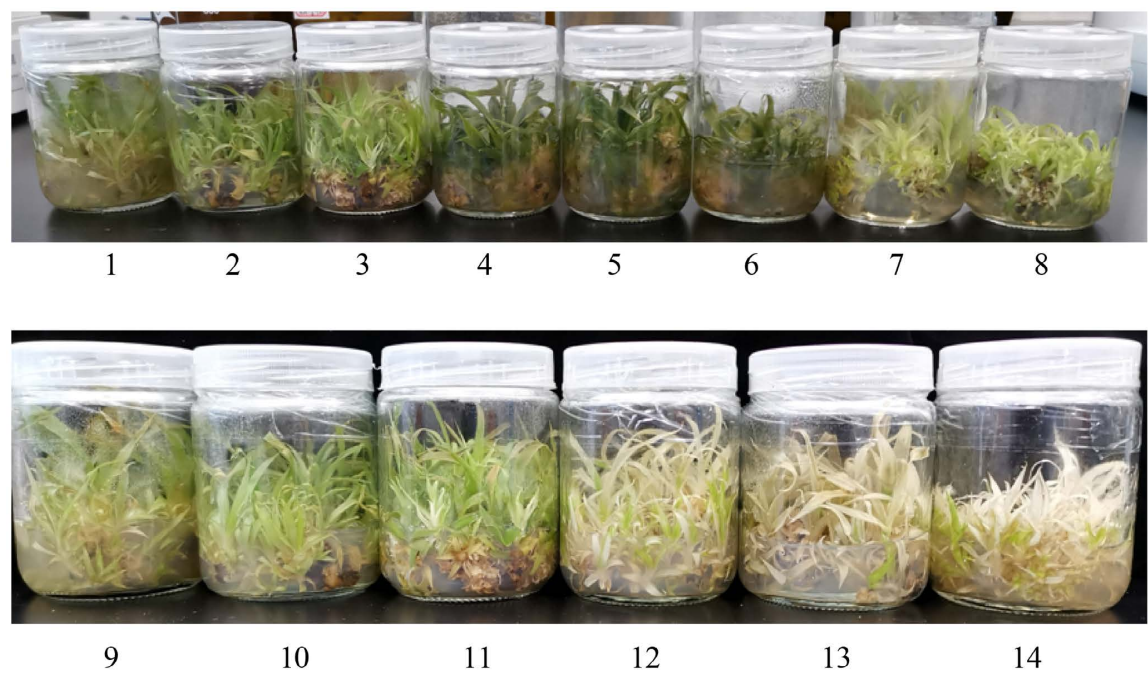

Figure 1. Pineapple seedlings cultured on MSO medium after treated with low temperature. 1 - 14 represented Tradsrithong, Smooth cayenne, Ripley, MD-2, Phetchaburi\#2, New Phuket, Bali, Perola, Niunai, Tainong 4, Xigua, Kallara local, Peral, Tainong 17 respectively. 
23 LEA genes, 1 HSP gene (Figure 3). Three hundreds and two locus were found arouns these genes (Figure 4). No locus was found around 36 genes. One SSR locus has been found around 43 genes. Two SSR loci were found around 31 genes. Three SSR loci were found around 22 genes. Four SSR loci were found around 10 genes. Five SSR loci were found around 5 genes. Six SSR loci were found around 7 genes. Seven SSR loci were found around 1 gene. Eight SSR loci were found around 1 gene. Aco020569.1, a basic helix-loop-helix bHLH DNA-binding superfamily protein had 8 SSR loci, which had the most.

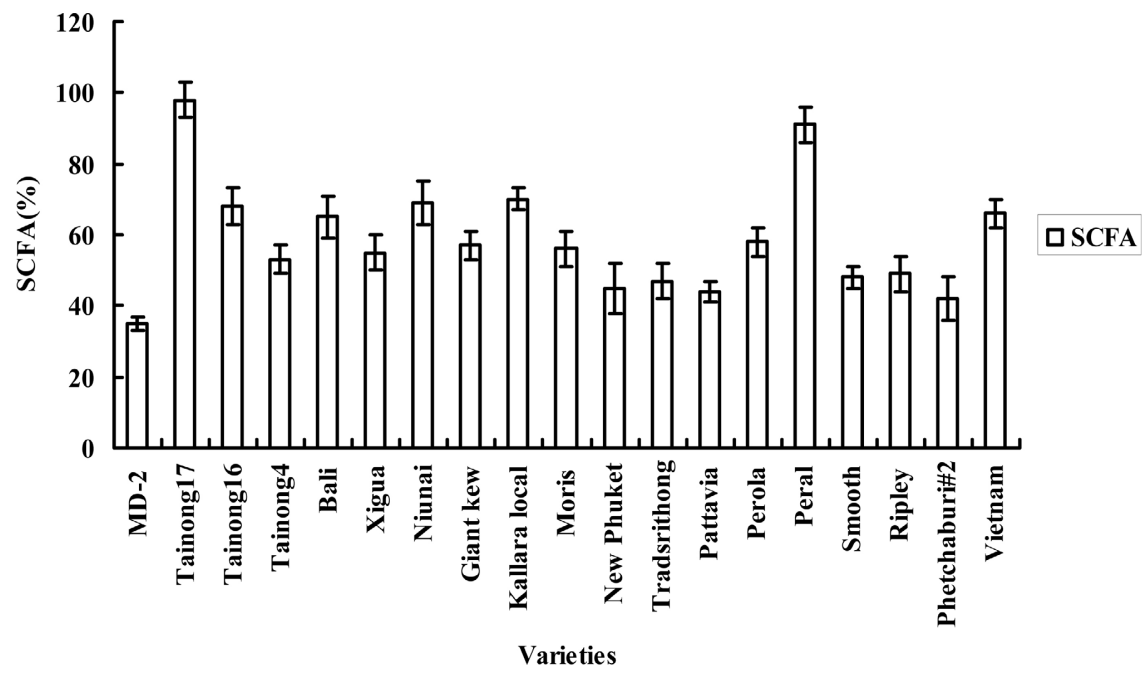

Figure 2. Scorched area of the fourth leaf from the apex (SCFA) of pineapple varieties.

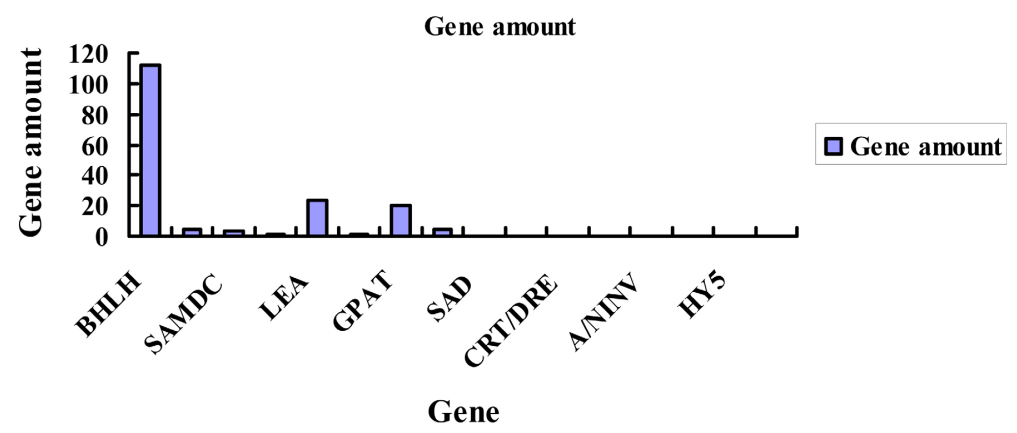

Figure 3. Homologous amounts of cold-tolerant genes in pineapple genome.

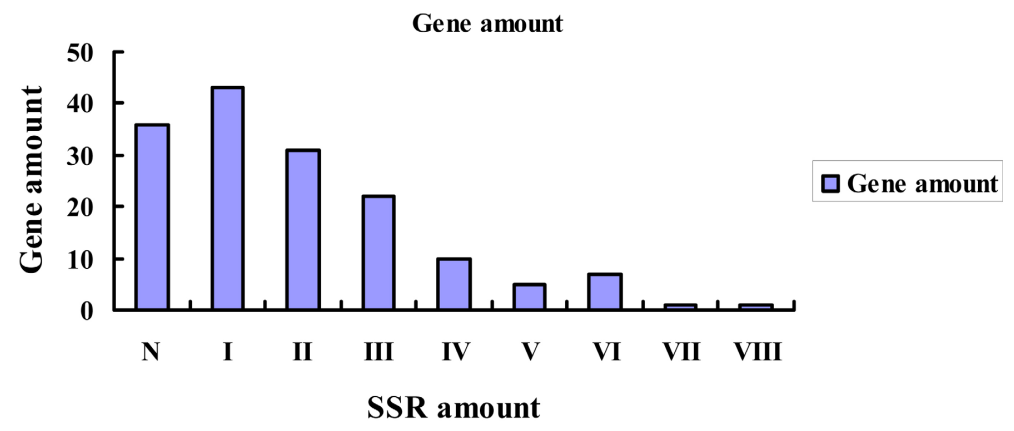

Figure 4. The distribution of SSR locus around cold-tolerant genes in pineapple genome. 
3) SSR primers screening

After all of the primers were screened with MD-2 and Tainong 17, PCR results of 73 pairs of primers showed different (Figure 5). These SSR loci located in

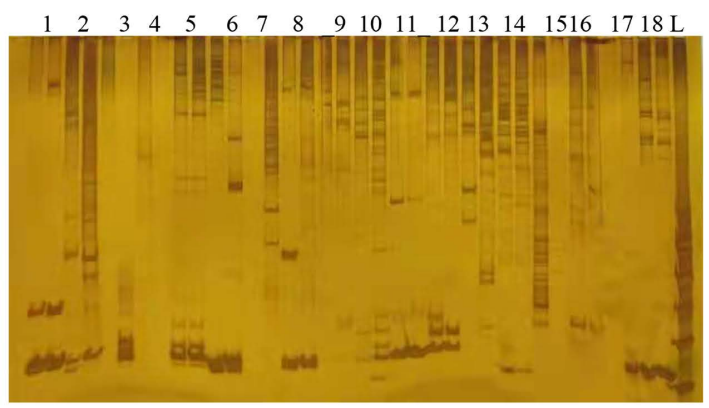

(a)

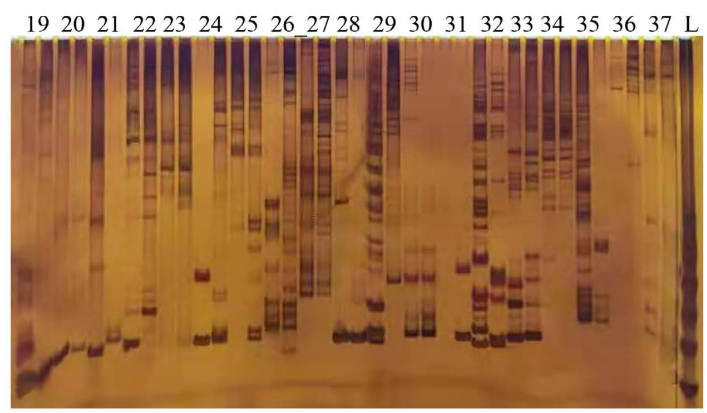

(b)

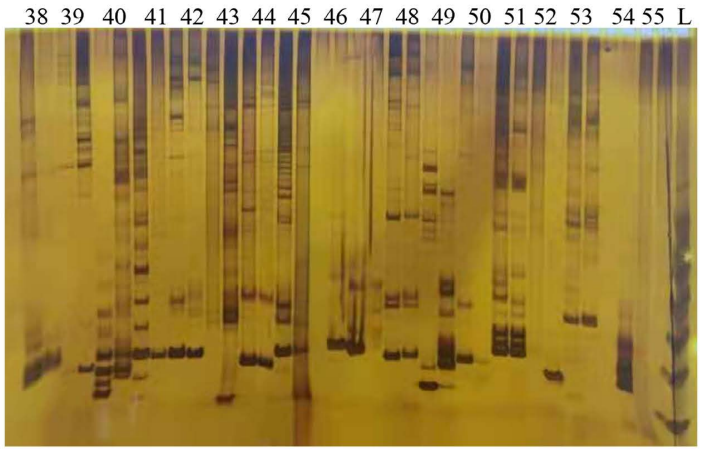

(c)

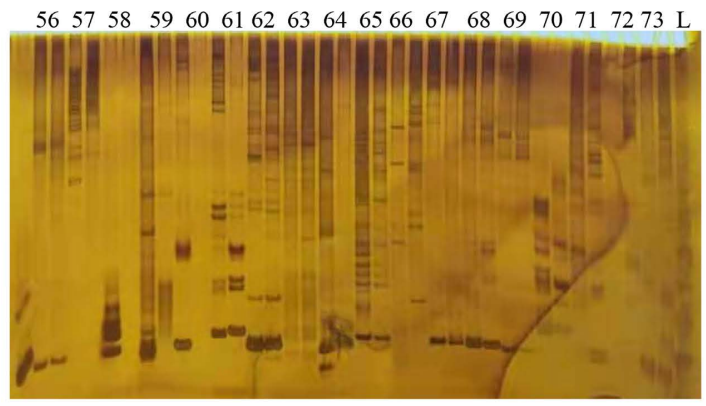

(d)

Figure 5. Partial primers of which PCR results were different between MD-2 and Tainong 17. 1 - 73 represented the primers. For each primer, the left lane was the PCR result from MD-2. The right lane was the PCRresult from Tainong 17. L was DNA ladder. 
chrosome $5,2,7,17,6,12,10,3,15,11,1,21,14,9,21,13,25,22,4,18$ respectively. Chrosome 3 had four SSRs of which PCR results were different between MD-2 and Tainong17. Chrosome 2 had 10 SSRs of which PCR results were different, which was the most among the chrosomes. Chrosome 5 had 8 SSR loci of which PCR results were different. Chrosome 15 had 7 SSRs of which PCR results were different. These SSRs can be used for identifying MD-2 and Tainong 17. SSRs related with cold tolerance might among them.

4) SSRs markers identification using pineapple varieties collected

The SSRs of which PCR results were different between MD-2 and Tainong 17 were used to identify the polymorphysium of the germplasms collected. Comparing with the cold tolerance identification of the seedlings, seven pairs of primers had good correlationship between PCR results and cold-tolerant identification (Figure 6). They might be used as molecular markers for predicting

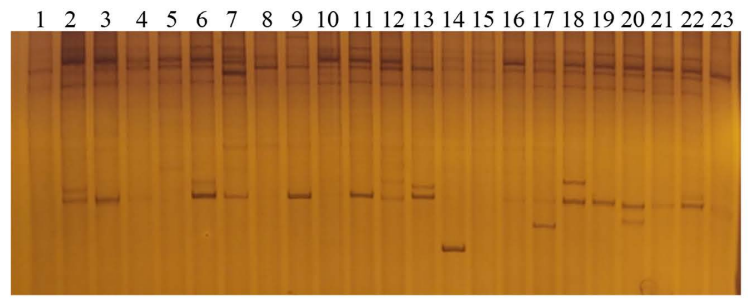

(a)

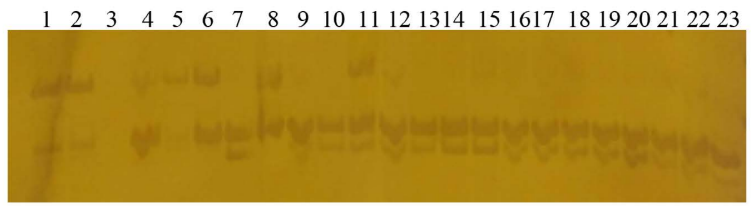

(b)

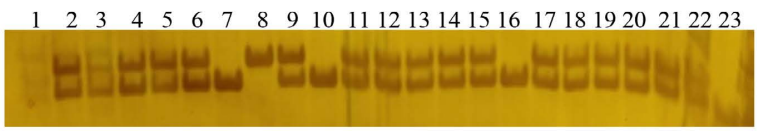

(c)

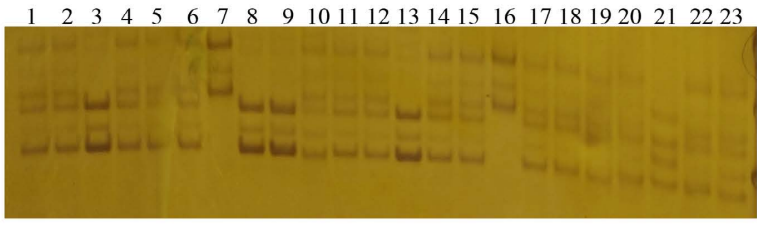

(d)

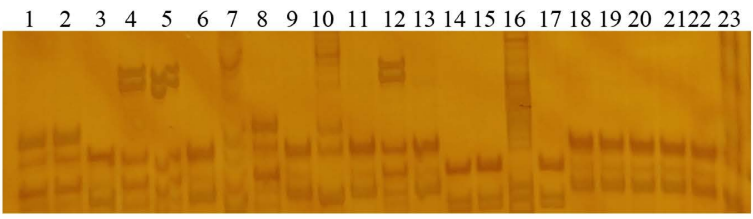

(e)

Figure 6. SSR identified using germplasms collected. A to E showed primers. Numbers represented pineapple germplasms. (a) S4490-2; (b) S15791-3; (c) S4138-1; (d) S4136-1; (e) S4459-2. 


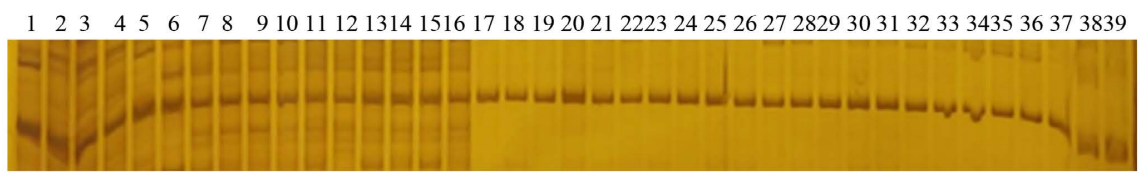

(a)

$1223 \quad 456678 \quad 9101112131415161718192021222324252627282930313233343536373839$

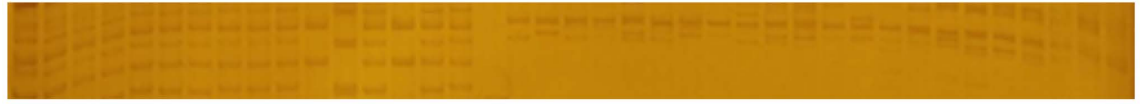

(b)

Figure 7. SSR markers were identified using cold-tolerant germplasms. A showed the primer S15158-2. B showed the primer S15158-3. (a) S15158-3; (b) S5354-1.

pineapple's cold tolerance character. Both S4490-2 and S15158-3 located in chromosome 5.

5) SSRs markers identification using pineapple varieties with high cold tolerance

To identify the SSR markers related with cold tolerance, pineapple materials with high cold tolerance were used. Twenty two pineapple plantlines were collected in field when cold wave passed. When these materials were used for identifying SSR markers, results showed that S15158-3 and S5354-1 had good consistence with cold-tolerance characters (Figure 7). This demonstrated that these two markers can be used for identifying pineapple cold-tolerant character.

\section{Discussion}

Identifying the cold tolerance of gerplasms was the necessary step for breeding pineapple cold-tolerant varieties. Molecular marker was an important method for identifying characters of germplasm. Sanewski (2020) identified molecular markers associated with spiny-tip margin character using genome-wide association study (GWAS) and quantitative trait loci (QTL) analysis [26]. The gene responsible for pineapple spiny-tip margin was positioned at 14,355,639 and $14,341,745$ bp respectively, on or very near, a zeaxanthin epoxidase (ZEP) gene [26]. Using DarTseq method, DArTseq molecular markers for resistance to Phytophthora cinnamomi in pineapple (Ananas comosus L.) were found in a single broad locus on chromosome five covering the positions 4.6 - 5.5 $\mathrm{Mb}$ and two separate scaffolds [27]. Thirteen putative resistance/susceptibility proteins were identified in these positions and might be responsible for resistance to Phytophthora cinnamomi [27].

Simple Sequence Repeat (SSR) markers or microsatellites are a powerful technique for quantifying levels of inter-species genetic variation. According to the genomic sequence information of Arabidopsis thaliana and Chinese Cabbage, gene sequences related to glucosinolates (GS) biosynthesis were alignment and analysis, finding 102 candidate genes associated with GS content distributed in 10 chromosomes [5]. The homologous genes for GS biosynthensis were detected in Chinese cabbage. By analyzing sequences of candidate genes and their up/down 
franking $5 \mathrm{~kb}$ nucleotides with software FASTPCR 6.0, 237 SSRs were developed in 102 genes [5]. Seventy seven SSR specific primers linked to GS synthesis genes could be designed from 86 genes with SSR locus [5]. Eleven pairs of primers were amplified in all accessions and produced 26 SSR alleles [5]. Using similar method, we found 169 homologous sequences of cold-tolerant genes in pineapple genome in this study. Three hundreds and two loci were found around these genes. After all of the primers were screened with MD-2 and Tainong 17, PCR results of 73 pairs of primers were found different. These SSRs located in chrosome $5,2,7,17,6,12,10,3,15,11,1,21,14,9,21,13,25,22,4,18$ respectively. These SSRs were screened among pineapple varieties. Results showed that seven pairs of primers had good consistence with cold-tolerant characters. When these SSRs markers were screened with cold-tolerance-identified plantlines, it was found that S15158-3 and S5354-1 had good consistence with cold-tolerant characters. This demonstrated that these two markers can be used for identifying pineapple cold-tolerant character and screening cold-tolerant germplasm.

\section{Acknowledgements}

This research was supported by State Key Project for Research and Development of China "Pineapple mutation breeding and creation new varieties with high quality” (No. 2019YFD1001104).

\section{Conflicts of Interest}

The authors declare no conflicts of interest regarding the publication of this paper.

\section{References}

[1] He, J. (2015) Pineapple New Varieties and Techniques on High Quality and Quantity. Chinese Agriculture Technique Press, Beijing.

[2] Chen, C., Zhang, Y., Xu, Z., Luan, A., Mao, Q., Feng, J., Xie, T., Gong, X., Wang, X., Chen, H. and He, Y. (2016) Transcriptome Profiling of the Pineapple under Low Temperature to Facilitate Its Breeding for Cold Tolerance. PloS ONE, 11, e0163315. https://doi.org/10.1371/journal.pone.0163315

[3] Williams, D.D.F. and Fleisch, H. (1993) Historical Review of Pineapple Breeding in Hawaii. First International Pineapple Symposium. Acta Horticulturae, 334, 67-76. https://doi.org/10.17660/ActaHortic.1993.334.7

[4] Wan, Y., Liu, H., Wu, L., Hu, B., Li, X., Gabriel, O.R. and Xie, J. (2009) Rapid DNA Fingerprinting of Rice Germplasms by Resistant Gene Analog Markers. Acta Agriculturae Jiangxi, 21, 1-5.

[5] Gong, H. (2014) Development and Application of SSR Markers Linked to Glucosinolate Synthesis Genes in Chinese Cabbage. Dissertation for Marster Degree, Hebei Agricultural University, Baoding.

[6] Liu, S., Wu, Q., Dou, M. and Sun, G. (2008) Investigation Report on Cold Resistance of Pineapple Germplasms. China Tropical Agriculture, 4, 33-35.

[7] Kodama, H., Hamada, T., Horiguchi, G., Nishimura, M. and Iba, K. (1994) Genetic Enhancement of Cold Tolerance by Expression of a Gene for Chloroplast $\omega$-3 Fatty 
Acid Desaturases in Transgenic Tobacco. Plant Physiology, 105, 601-605. https://doi.org/10.1104/pp.105.2.601

[8] Peng, D., Zhou, B., Jiang, Y.Q., Tan, X.F., Yuan, D.Y. and Zhang L. (2018) Enhancing Freezing Tolerance of Brassica napus L. by Overexpression of a Stearoyl-Acyl Carrier Protein Desaturase Gene (SAD) from Sapium sebiferum (L.) Roxb. Plant Science, 272, 32-41. https://doi.org/10.1016/j.plantsci.2018.03.028

[9] Tian, Q.Q., Chen, J.H., Wang, D., Liu, C., Wang, S., Xia, X.L. and Yin W.L. (2017) Overexpression of a Populus euphratica CBF4 Gene in Poplar Confers Tolerance to Multiple Stresses. Plant Cell, Tissue and Organ Culture, 128, 391-407. https://doi.org/10.1007/s11240-016-1118-y

[10] Xu, H.F., Wang, N., Wang, Y.C., Jiang, S.H., Fang, H.C., Zhang, J., Su, M.Y., Zuo, W.F., Xu, L., Zhang, Z.Y. and Chen, X.S. (2018) Overexpression of the Transcription Factor MdbHLH33 Increases Cold Tolerance of Transgenic Apple Callus. Plant Cell, Tissue and Organ Culture, 134, 131-140. https://doi.org/10.1007/s11240-018-1406-9

[11] Cao, N., Zhang, Q.X., Hao, R.J., Xu, Z.D., Wang, T. and Yang, W.R. (2014) Molecular Cloning and Expression Analysis of Coldresistant Transcription Factor PmICE1 from Prunus mume. Journal of Northeast Forestry University, 42, 21-25.

[12] Yang, Y.F., Wu, J., Zhu, K., Liu, L.Q., Chen, F.D. and Yu, D.Y. (2016) Overexpression of DmDREBa Gene Significantly Enhances Low Temperature Tolerance in Transgenic Tobacco. Bulletin of Botanical Research, 36, 721-729.

[13] Steponkus, P.L., Uemura, M., Joseph, R.A., Gilmour, S.J. and Thomashow M.F. (1998) Mode of Action of the COR15a Gene on the Freezing Tolerance of Arabidopsis thaliana. Proceedings of the National Academy of Sciences of the United States of America, 95, 14570-14575. https://doi.org/10.1073/pnas.95.24.14570

[14] Zhao, M.M., Liu, H., Deng, Z., Chen, J.S., Yang, H., Li, H.P., Xia, Z.H. and Li D.J. (2017) Molecular Cloning and Characterization of $S$-Adenosylmethionine Decarboxylase Gene in Rubber Tree (Hevea brasiliensis). Physiology and Molecular Biology of Plants, 23, 281-290. https://doi.org/10.1007/s12298-017-0417-Z

[15] Wang, L., Yao, L., Hao, X.Y., Li, N.N., Qian, W.J., Yue, C., Ding, C.Q., Zeng, J.M., Yang, Y.J. and Wang, X.C. (2018) Tea Plant SWEET Transporters: Expression Profiling, Sugar Transport, and the Involvement of CsSWEET16 in Modifying Cold Tolerance in Arabidopsis. Plant Molecular Biology, 96, 577-592.

https://doi.org/10.1007/s11103-018-0716-y

[16] Balamurugan, S., Ann, J.S., Varghese, I.P., Murugan, S.B., Harish, M.C., Kumar, S.R. and Sathishkumar, R. (2018) Heterologous Expression of Lolium perenne Antifreeze Protein Confers Chilling Tolerance in Tomato. Journal of Integrative Agriculture, 17, 1128-1136. https://doi.org/10.1016/S2095-3119(17)61735-0

[17] Liu, Y.L., Xie, L.X., Liang, X.L. and Zhang, S.L. (2015) CPLEA5, the Late Embryogenesis Abundant Protein Gene from Chimonanthus praecox, Possesses Low Temperature and Osmotic Resistances in Prokaryote and Eukaryotes. International Journal of Molecular Sciences, 16, 26978-26990. https://doi.org/10.3390/ijms161126006

[18] Zhuo, C.L., Liang, L., Zhao, Y.Q., Guo, Z.F. and Lu, S.Y. (2018) A Cold Responsive Ethylene Responsive Factor from Medicago falcata Confers Cold Tolerance by Up-Regulation of Polyamine Turnover, Antioxidant Protection, and Proline Accumulation. Plant, Cell \& Environment, 41, 2021-2032.

https://doi.org/10.1111/pce.13114

[19] Dahro, B., Wang, F., Peng, T. and Liu, J.H. (2016) PtrA/NINV, an Alkaline/Neutral Invertase Gene of Poncirus trifoliata, Confers Enhanced Tolerance to Multiple Abi- 
otic Stresses by Modulating ROS Levels and Maintaining Photosynthetic Efficiency. BMC Plant Biology, 16, Article No. 76. https://doi.org/10.1186/s12870-016-0761-0

[20] Wolter, F. P., Schmidt, R. and Heniz, E. (1992) Chilling Sensitivity of Arabidopsis thaliana with Genetically Engineered Membrane Liquids. The EMBO Journal, 11, 4685-4692. https://doi.org/10.1002/j.1460-2075.1992.tb05573.x

[21] Zhang, L., Sun, L., Zhang, L., Qiu, H., Liu, C., Wang, A., Deng, F. and Zhu, J. (2017) A $\mathrm{Cu} / \mathrm{Zn}$ Superoxide Dismutase Gene from Saussurea involucrata Kar. \& Kir., SiCSD, Enhances Drought, Cold and Oxidative Stress in Transgenic Tobacco. Canadian Journal of Plant Science, 97, 816-826. https://doi.org/10.1139/CJPS-2016-0180

[22] An, J.P., Yao, J.F., Wang, X.N., You, C.X., Wang, X.F. and Hao, Y. J. (2017) MdHY5 Positively Regulates Cold Tolerance via CBF-Dependent and CBF-Independent Pathways in Apple. Journal of Plant Physiology, 218, 275-281.

https://doi.org/10.1016/j.jplph.2017.09.001

[23] Wang, M., Zou, Z.W., Li, Q.H., Xin, H.H., Zhu, X.J., Chen, X. and Li, X.H. (2017) Heterologous Expression of three Camellia sinensis Small Heat Shock Protein Genes Confers Temperature Stress Tolerance in Yeast and Arabidopsis thaliana. Plant Cell Reports, 36, 1125-1135. https://doi.org/10.1007/s00299-017-2143-y

[24] Qiu, H.L., Zhang, L.H., Liu, C., He, L., Wang, A.Y., Liu, H.L. and Zhu, J.B. (2014) Cloning and Characterization of a Novel Dehydrin Gene, SiDhn2, from Saussurea involucrata Kar. et Kir. Plant Molecular Biology, 84, 707-718. https://doi.org/10.1007/s11103-013-0164-7

[25] Ma, L., Zhang, J., Huang, G., Li, Y., Li, X. and Zheng, Y. (2014) Molecular Characterization of Cotton C-Repeat/Dehydrationresponsive Element Binding Factor Genes that Are Involved in Response to Cold Stress. Molecular Biology Reports, 41, 4369-4379. https://doi.org/10.1007/s11033-014-3308-1

[26] Sanewski, G.M. (2020) DArTseq Molecular Markers Associated with the Spiny-Tip Leaf Margin in Pineapple (Ananas comosus L.). Tropical Plant Biology, 13, 91-116. https://doi.org/10.1007/s12042-019-09245-Z

[27] Sanewski, G., Ko, L., Innes, D., Kilian, A., Carling, J. and Song, J. (2017) DArTseq Molecular Markers for Resistance to Phytophthora cinnamomi in Pineapple (Ananas comosus L.). Australasian Plant Pathology, 46, 499-509.

https://doi.org/10.1007/s13313-017-0512-1 